\section{HEAT INSULATION IN ELECTRIC POWER STATIONS}

$\mathrm{H}^{\mathrm{s}}$ AT insulation of pipes, boilers and generating sets, which used to be indicated by the general term 'lagging', has now become an art in itself and, to obtain the best results, the material must be graded and applied in a totally different manner for high-, medium- and low-temperature pipe lines and surfaces. In a paper presented at a semi-annual meeting in Milwaukee to the American Society of Mechanical Engineers by Messrs. E. T. Cope and W. F. Kinney, engineers to the Detroit Edison Co., the authors point out that in water-cooled boiler furnaces used in steam generating plants, it is common experience to find that cracks develop in the insulation on water-cooled furnace walls as the result of : (a) expansion and contraction of the setting, $(b)$ shrinkage of the material, (c) settling of the material or (d) loosening of the material due to faulty attachment. Because of the likelihood of air infiltration as a result of this situation and to provide a pleasing external appearance, it is frequently considered necessary to encase waterwall furnaces in airtight steel shells, which in turn may require insulation.

Experience has shown that it is virtually impossible to maintain airtight any of the assemblies used in practice unless all-welded steel casings are used, but this is an elaborate and expensive construction and no satisfactory economical method has yet been found. Large areas comprising air-ducts, breechings, fan-housings, tanks and similar equipment are subject to vibration and considerable expansion and contraction. The presence of hot gases varying from perhaps $100^{\circ}$ to $600^{\circ} \mathrm{F}$. on the inside of the wall with insulation on the exterior is conducive to a great deal of warping and irregular movement, which in turn affects the tightness of the insulation. To provide for this movement, expansion joints are usually installed in various locations on the equipment. It is difficult to retain blocks, blankets, or insulating cement on a surface where so much relative movement and vibration takes place. Unless extreme precautions are taken during the installation, loosening of the insulation will be a recurring problem.

Large pipe-bends are still covered with doublelayer block insulation, leaving an expansion joint covered with curly glass wool at both ends of each bend.

The selection of thermal insulation for steam turbines is a problem that presented few difficulties in the past, when the operating steam temperatures were well within the temperature limit for asbestos and magnesia products. In recent years the design of steam-generating equipment and turbines has advanced so rapidly in the direction of higher steam temperatures that severe operating conditions are imposed on insulating materials.

Plastic insulating cement has grown in favour because it permits easy application over the irregularities in the turbine shell, but it must be applied in layers, preferably less than 2 in. thick, covered with reinforcing netting secured to lugs on the casing, and trowelled with a finishing cement-a procedure which requires several days to permit adequate drying of each layer on a cold surface. It is questionable whether admitting steam to the turbine to expedite drying of the plastic insulation is an acceptable operating practice, due to the possibility of inducing unequal stresses in the bolts, flanges and appendages.
The advantages of flexibility and low thermal conductivity of reinforced open-face flexible insulating blankets are offset by the widespread objection to having around the turbine a loose wool that may become detached from its backing, and to the difficulty of cutting the metal mesh reinforcement to fit.

Finally the following conclusions, among others, are reached : (a) Insulating pads, composed of a textile jacket enclosing a loose filler, appear to be the most desirable form of insulation for turbines. (b) As determined by extensive field tests, there is one brand of glass fabric pad with glass-wool filler that is preferred for temperatures up to $1,050^{\circ} \mathrm{F}$., and two brands of reinforced white asbestos pads with either mineral-wood or amosite asbestos fibre filler are considered reasonably acceptable. (c) From actual installations on various sized turbines operating at different steam temperatures from $700^{\circ}$ to $910^{\circ} \mathrm{F}$., it was concluded that $50^{\circ} \mathrm{F}$. appears to be a reasonable temperature difference between the outside surface of the insulation and the ambient air.

\section{APPOINTMENTS VACANT}

APPHOATIONs are invited for the following appointments on or before the dates mentioned :

assistant Master to take Enginegring Workshop Praotior AND ALLIED SUBJbcTs in the Willesden Technical College-Dr. E. Davies, Education Offoces, Dyne Road, Kilburn, London, N.W.6 (January 15).

LECTURER in MEChaNical BNgINEERING-The Registrar, Wimbledon Technical College, Gladstone Road, London, S.W.19.

Primary EddCation OFFICER (MALE) for the Education Department of the Government of Kenya-The Crown Agents for the Colonies, 4 Millbank, London, S.W.1 (quoting M/9531).

\section{REPORTS AND OTHER PUBLICATIONS}

(not included in the monthly Books Supplement)

\section{Great Britain and Ireland}

Ministry of Health : Ministry of Home Security. Recommendations of Lord Horder's Committee regarding the Conditions in Air-Raid Shelters, with Special Reference to Health; and a Brief Statement of Action taken by the Government Thereon. (Cmd. 6234.) Pp. 7.
(London: H.M. Stationery Office.) 2d. net.
[2i1i London: H.M. Stationery Office.) 2d. net.
Freshwater Biological Association of the British Empire. Scientiflc Publication No. 3: The Food of Coarse Fish; being the Interim Report on the Coarse Fish Investigation. By P.' H. T. Hartley. Pp. 33. (Ambleside : Freshwater Biological Association.) 18. 6d. [261i The British Academy. Presidential Address, 10 July 1940. By 26). Pp. 8. (Iondon: Oxford University Press.) bd. net.

\section{Other Countries}

Commonwealth of Australia : Council for Scientiflc and Industrial Research. Fisheries Circular No. 1: Some Notes on the Smoking of Fish. By E. J. Ferguson Wood. Pp. 6. (Melbourne: Government Printer.)

Bulletin of the American Museum of Natural History. Vol. 77, Art. 6: The Spiders of Texas, I. By W. J. Gertsch and 8. Mulaik. Pp. 307-340. (New York: American Museum of Natural History.) [2711 Annual Report on the Forest Administration of Nigeris for the Year 1939. Pp. 37. (Lagos: Government Printer ; Iondon: Crown Agents for the Colonies.) 1s. $6 d$. $[2711$

The Cooper Union for the Advancement of Bcience and Art. Eightyflrst Annual Report, July 1, 1940. Pp. lii +141. (New York: The Cooper Union for the Advancement of Science and Art.) $[212$

U.S. Department of the Interior: Offlce of Education. Vocational Division Bulletin No. 204 (Occupational Information and Guidance Series No. 1) ; Occupational Information and Guidance; Organization and Administration. With a Brief Survey of the Development of Harry A. Jager and Giles M. Ruch. Pp. vil +181. (Washington, D.C.: Harry A. Jager and Giles M. Ruch. Pp. vil +181. (Washington, D.C.:
Government Printing Office.) 25 cents. Statens Meteorologisk-Hydrograflska Anstalt. Arsbok, 19, 1937. vil. Meteorologiska iakttagelser i Riksgränsen. Pp. 44. $4.00 \mathrm{kr}$. Arsbok, 21, 1939. ii. Nederbörden i Sverige. Pp. $15+1$ plate. $2.50 \mathrm{kr}$. Meddelanden, No. 32: The Lag-Coefficient of Aerological Instruments and the Function of Hair Hygrometers at Low Temperatures. By Alf Nyberg. Pp. 20. Meddelanden, Band 7, No. 7: Várflödet i Norrlåndska vattendrag samt i Dalälven och Klarălven. Av Folke Bergsten. Pp. 14. $1.50 \mathrm{kr}$. (Stockholm: P. A. Norstedt and Sorner.) 